\title{
Assessment of physical land suitability by GIS-based fuzzy AHP for rubber plantation at the Nam Dong district, Thua Thien Hue province
}

\author{
Ưng dụng GIS và Fuzzy AHP đánh giá sự thích nghi tự nhiên cho loại hình sử dụng đất trồng \\ cây cao su trên địa bàn huyện Nam Đông, tỉnh Thừa Thiên Huế
}

\author{
TRAN, Thi Minh Chau*; LE, Dinh Huy; LE, Ngoc Phuong Quy; NGUYEN, Thi Hai; TRAN, Trong \\ Tan; TRINH, Ngan Ha
}

University of Agriculture and Forestry, Hue University, Vietnam

\begin{abstract}
This research was conducted to determine the main influences and physical factors of land suitability for rubber plantation in the Nam Dong district, Thua Thien Hue province. Six factors such as soil type, soil texture, soil thickness, slope, soil pH and soil organic matter content were considered. Results indicate that soil thickness is has the highest role on the land suitability analysis while soil pH has the lowest. The physical land suitability of rubber plantation was divided into 4 levels: very suitable (10.1\%), suitable (15.5\%), slightly suitable (3.6\%), and currently not suitable (70,8\%). This research provides important information for rubber cultivation in projected agricultural land use planning of the Nam Dong district.
\end{abstract}

\begin{abstract}
Nghiên cứu này được thực hiện nhằm xác định sự ảnh hưởng của các yếu tố tự nhiên đến sự thích nghi đất đai của loại hình sử dụng đất trồng cây cao su trên địa bàn huyện Nam Đông, tỉnh Thừa Thiên Huế. Có 6 yếu tố được xem xét trong nghiên cứu này bao gồm: loại đất, thành phần cơ giới, tầng dày canh tác, độ dốc, độ chua và hàm lượng mùn trong đất. Kết quả nghiên cứu chỉ ra rằng tầng dày canh tác là yếu tố có ảnh hưởng lớn nhất đến việc sử dụng đất trồng cây cao su, trong khi đó độ chua là yếu tố có ảnh hưởng ít nhất. Sự thích nghi tự nhiên của loại hình sử dụng đất trồng cây cao su được chia thành 4 mức độ bao gồm rất thích nghi (10,1\%), thích nghi (15,5\%), tương đối thích nghi (3,6\%) và hiện taị không thích nghi (70,8\%). Nghiên cứu này cung cấp những thông tin cần thiết và hữu ích cho việc quy hoạch sử dụng đất trồng cây cao su trên địa bàn huyện Nam Đông.
\end{abstract}

Keywords: physical land suitability; rubber plantation; Nam Dong district

\section{Introduction}

Agriculture is main livelihood of most Vietnamese people, contributing not only to economics but also having an important role for social aspects (Nguyen H.H, Pham V.V, \& Khuong M. H, 2019). There are many factors impacting agricultural production such as agricultural and rural development policies. Among them, the sustainable use of land is considered as a key solution. Nowadays, the extension of arable land is decreasing due to multiple reasons such as population explosion, urbanization and the negative effects of climate change. Therefore, land evaluation is necessary for agricultural sustainability in future (Selassie, Ayalew, Elias, \& Getahun, 2014). Making effective decisions regarding agricultural land suitability problems is vital to achieve optimum land productivity and to ensure environmental sustainability (Heliza, Rahmat, Fahrul, \& Tarbiyatul, 2014); land evaluation is an important tool task of this process.
The main aim of land evaluation is to reduce the impact of human on natural resources and identify the suitability land using $(\mathrm{H}$. I. Mohammed, Z. Majid, N. B. Yusof, \& Y. B. Yamusa, 2017). Land evaluation is one part of the of land use planning processes. The result of land evaluation provides data as the base on which decisions can be taken (FAO, 1976). For land suitability analysis, soil information, in both spatial and attribute data, is very important since it not only contains the attribute data but also shows spatial distribution (AbdelRahman, Natarajan, \& Hegde, 2016). There are some GIS-based approaches for land suitability evaluation that have been applied worldwide. Among them, the combination of GIS and multi-criteria evaluation is considered as the most popular (Debesa et al., 2020; Nguyen H.H et al., 2019). Fuzzy Analytical Hierarchy Process (FAHP) is a method derived from AHP which was first developed by Thomas L. Saaty (Ayhan, 2013; Nguyen, Hoang Khanh Linh, Jan, Nguyen, \& Tran, Thi Minh Chau, 2018). 
Based on fuzzy set theory, FAHP is an efficient tool to handle the uncertainty and vagueness of the expert's opinion (Herzberg, Pham, Kappas, Wyss, \& Tran, Chau Thi Minh, 2019). In FAHP, a pair wise comparisons for both, criteria and the alternatives, is performed through the linguistic variables which are represented by triangular numbers to establish comparison matrices (Asakereh, Soleymani, \& Sheikhdavoodi, 2017; Fahrul, Rahmat, \& Heliza, 2014).

Nam Dong is a mountainous district of the Thua Thien Hue province where 6 different ethnic groups currently live. Similarly, to other hilly regions in Vietnam, agriculture is main livelihood of local people. During the last few decades, supporting programs from Government and Non-Government agencies have been implemented in this district to enhance the economic situation of local residents. As part of such programs, rubber trees were planted in many areas, however, there was not a clear conclusion about the suitability of this kind of tree for production in the Nam Dong district. Assessment of land suitability for rubber plantation is an important solution to help the local government on making more accurate agriculture planning decisions.

\section{Methods}

\subsection{Soil sampling}

Soil sampling was implemented following the grid-based system, with a grid size of $2.5 \mathrm{~km} \times 2.5 \mathrm{~km}$ and based on the land unit map. The land unit map was developed by overlapping the thematic maps including: soil types, soil texture, soil thickness, and land use types. Each soil sample was collected from 3 separated soil layers at different depths based on soil thickness (Table 1). There were 112 soil samples collected in May of 2020.

Table1. The soil sampling depth correlates to the soil thickness

\begin{tabular}{ll} 
Soil thickness & Soil sampling depth \\
\hline$<30 \mathrm{~cm}$ & $10 \mathrm{~cm}, 20 \mathrm{~cm}, 30 \mathrm{~cm}$ \\
$30-50 \mathrm{~cm}$ & $10 \mathrm{~cm}, 30 \mathrm{~cm}, 50 \mathrm{~cm}$ \\
$50-70 \mathrm{~cm}$ & $10 \mathrm{~cm}, 30 \mathrm{~cm}, 50 \mathrm{~cm}$ \\
$70-100 \mathrm{~cm}$ & $20 \mathrm{~cm}, 40 \mathrm{~cm}, 60 \mathrm{~cm}$ \\
$>100 \mathrm{~cm}$ & $20 \mathrm{~cm}, 40 \mathrm{~cm}, 60 \mathrm{~cm}$ \\
\hline
\end{tabular}

\subsection{Soil sample analysis}

The collected soil samples were air-dried at room temperature previous to the soil $\mathrm{pH}$ and the organic matter content analysis. The determination of organic matter content is based on the Walkley - Black chromic acid wet oxidation method. To measure soil $\mathrm{pH}, \mathrm{a} \mathrm{KCl}$ solution (1-mol/l) was mixed with $10 \mathrm{~g}$ of soil at a ratio of 1:5; the $\mathrm{pH}$ was measured with a $\mathrm{pH}$ meter.

\subsection{Fuzzy AHP method}

The FAHP method is use to solve the fuzziness in decisionmaking problems based on the matrix of pair -wise comparisons between fuzzy parameters (Asakereh, A., Soleymani, M., \& Sheikhdavoodi, M. J., 2017). First, the linguistic variables are defined with rating levels as showed in Table 2.

\section{Table 2. Description of linguistic variables in FAHP}

\begin{tabular}{ll} 
Linguistic variables & Triangular Fuzzy number \\
\hline Equally important & $(1,1,1)$ \\
Moderately more important & $(2,3,4)$ \\
Strongly more important & $(4,5,6)$ \\
Very strongly more important & $(6,7,8)$ \\
Extremely more important & $(9,9,9)$ \\
Intermediary value & $(1,2,3) ;(3,4,5) ;(5,6,7) ;(7,8,9)$ \\
\hline
\end{tabular}

After obtaining the fuzzy parameter values, the matrix of pairs-wise comparisons between the factors affecting the land use of rubber trees was established. By solving the matrix, the weight value, or the degree of influence of each element, was estimated. In the FAHP model, attention should be paid to the value of consistency (CR); a CR $<10 \%$ means that the comparison matrix is consistent and the related results would be highly accurate.

There are 12 participants, who are officials of Agricultural Department of Thua Thien Hue and Agricultural and Rural Development Division of Nam Dong district, involved to the survey which was conducted on the September of 2020. In our research, there are 6 main factors selected for FAHP including: soil type, soil texture, soil thickness, slope, $\mathrm{pH}$ KCl and soil organic matter (SOM). The data related to soil physical characteristics was collected from the Natural Resources and Environment Department of the Thua Thien Hue Province. There are 5 main soil types in the research area in which the Xanthic Ferralsols is the major.

\subsection{Land suitability evaluation based on a combined approach between GIS and FAHP}

To make decisions on assessing the natural adaptability to rubber plantations, this study uses a land adaptation assessment model as shown in the Figure 1. For each factor, a score of impact was defined based on the practical experience of the soil experts and local officials. These scores $\left(X_{i}\right)$ are combined with the weights of the factors (Wi) to calculate the adaptability level according to the formula:

$$
\mathrm{Si}=\sum \mathrm{Wi}_{\mathrm{i}} * \mathrm{Xi}
$$

where $\mathrm{Si}$ is the land suitability level; $\mathrm{Wi}$ is the weight value of each influencing factor; $X_{i}$ is the attribute score of each factor. 


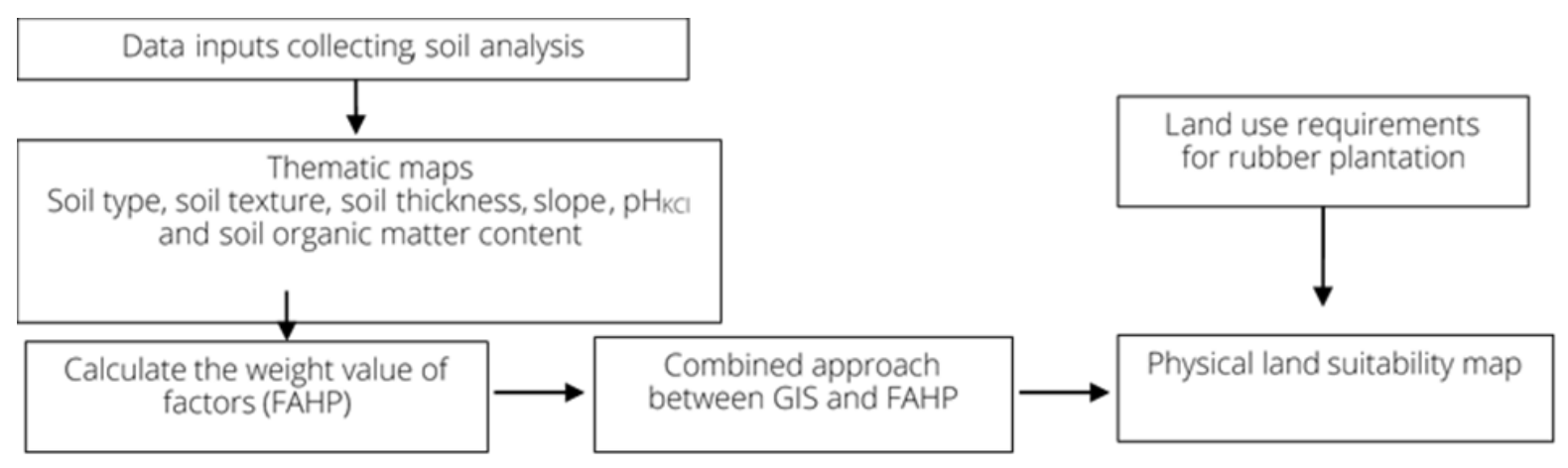

Figure 1. Procedure of physical land suitability mapping for rubber plantation

The calculation process was performed on GIS software. The land suitability classification levels for rubber trees are shown in Table 3.

\section{Table 3. Land suitability classification}

\begin{tabular}{lll} 
Score & Land suitability level & Description \\
\hline $3.26-4.0$ & S1 & Very suitable \\
$2.51-3.25$ & S2 & Suitable \\
$1.76-2.5$ & S3 & Slightly suitable \\
$1.0-1.75$ & $\mathrm{~N}$ & Currently not suitable \\
\hline
\end{tabular}

\section{Research results and discussion}

\subsection{Mapping land unit}

Land unit maps of the Nam Dong district are created from single-property maps including: soil type, thickness, slope, soil texture and organic matter content. Thematic maps were created on the basis of inheritance, field investigation, soil sampling and analysis in combination with GIS tools and interpolation methods. The land unit map displayed in Figure 2.

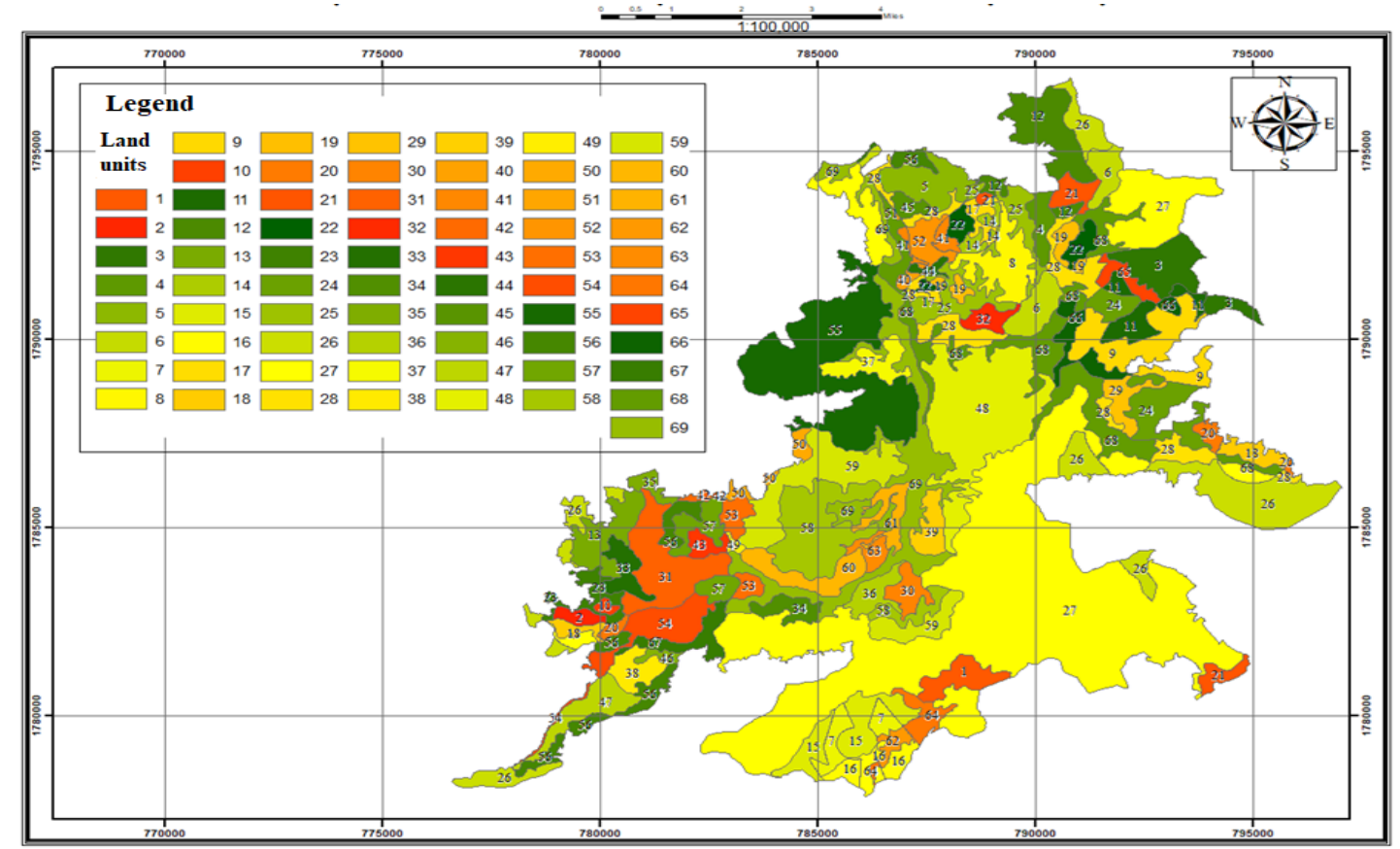

Figure 2. Land unit map in the study area of Nam Dong district

The map shows that in the study area there are a total of 69 land units for land evaluation for rubber plantation, a total area of $16,262.745$ ha. The soil type map shows Xanthic Ferralsols accounts for more than 55\% of the total area; some other soil types such as Plinthic Acrisols and Dystric Fluvisols account for very small proportions. In terms of soil texture, the clay group accounts for more than 55\% of the total area while the remainder seems to be equally divided between silty clay loam and sandy loam.
Soil thickness in Nam Dong district fluctuates in a range from 30 to $70 \mathrm{~cm}$; areas with soil layer of less than $30 \mathrm{~cm}$ and greater than $100 \mathrm{~cm}$ are minimal. The terrain on the study area is relatively flat, with slope rates ranging from 0 to 8 degrees for in approximately $65 \%$ of the total area. The results of soil analysis showed that soil acidity in the Nam Dong district varies from 4.5 to 5 while the humus content in the soil was greater than $2 \%$. This accounts for more than $60 \%$ of the total area. 
This is relatively consistent with actual conditions in the hilly and mountainous areas in Vietnam where agricultural production is located.

\subsection{The importance of selected factors for rubber plantation}

There are many natural factors that affect the growth and development of rubber trees; however, the magnitude of their effects is not the same among factors. The determination and ranking of the factors influence are necessary conditions to assess the natural adaptation. A factor with a high weight means that its degree of influence is also high. The weights of the factors were calculated using the pair comparison matrix, based on the opinions of experts and the FAHP method. The pair comparison matrix for the factors influencing rubber plantation is shown in Table 4.

Table 4. Pair comparison matrix by FAHP method

\begin{tabular}{|c|c|c|c|c|c|c|c|c|}
\hline & Soil type & Soil texture & Soil thickness & Slope & ph & & & SOM \\
\hline Soil type & $\begin{array}{lll}1 & 1 & 1\end{array}$ & 345 & $1 / 6 \quad 1 / 5 \quad 1 / 4$ & 113 & 4 & 5 & 6 & 456 \\
\hline Soil texture & $1 / 51 / 41 / 3$ & 111 & 234 & 234 & 2 & 3 & 4 & 234 \\
\hline Soil thickness & 456 & $1 / 4 \quad 1 / 3 \quad 1 / 4$ & 111 & 123 & 5 & 6 & 7 & 234 \\
\hline Slope & $1 / 3 \quad 1 / 2 \quad 1$ & $1 / 4 \quad 1 / 3 \quad 1 / 2$ & $1 / 3 \quad 1 / 21$ & 111 & 1 & 2 & 3 & 123 \\
\hline $\mathrm{pH}$ & $1 / 6 \quad 1 / 5 \quad 1 / 4$ & $1 / 4 \quad 1 / 3 \quad 1 / 2$ & $1 / 7 \quad 1 / 6 \quad 1 / 5$ & $1 / 3 \quad 1 / 21$ & 1 & 1 & 1 & $1 / 41 / 31 / 2$ \\
\hline SOM & $1 / 6 \quad 1 / 5 \quad 1 / 4$ & $1 / 4 \quad 1 / 3 \quad 1 / 2$ & $1 / 4 \quad 1 / 3 \quad 1 / 2$ & $1 / 3 \quad 1 / 21$ & 2 & 3 & 4 & $\begin{array}{lll}1 & 1 & 1\end{array}$ \\
\hline
\end{tabular}

Finally, according a CR of less than 10\% means that the calculation results are reliable and can be used to construct a natural soil adaptive zoning maps for rubber cultivation in the study area. The weight of each factor that influencing rubber plantation is shown in Table 5.
The results showed that soil thickness is the most influential factor with a weight of 0.275 . The remaining factors also affecting land use include soil type, soil texture and slope with weights of $0.254,0.229$ and 0.107 respectively.

\section{Table 5. Weight of factors influencing rubber plantation}

\begin{tabular}{lll} 
Factors & Weighted & Ratings \\
\hline Soil type & 0.254 & 2 \\
Soil texture & 0.229 & 3 \\
Soil thickness & 0.275 & 1 \\
Slope & 0.107 & 4 \\
pH & 0.051 & 6 \\
Soil organic matter & 0.083 & 5 \\
CR $=0.088$ & & \\
\hline
\end{tabular}

Soil organic matter content and $\mathrm{pH}$ are the two factors that have little influence on the analysis (the weight for both factors is 0.134). From each impact criterion, based on the requirements on the growth and adaptive properties of rubber trees, the study conducted a classification and score process according to the suitability level; very suitable, suitable, less suitable and not suitable match the corresponding scores of 4, 3, 2, 1 as displayed in Table 6.

\section{Table 6. Scores for each factor value}

\begin{tabular}{|c|c|c|c|c|c|}
\hline Criteria & Value & Scores & Criteria & Value & Scores \\
\hline \multirow[t]{4}{*}{ Soil type } & Humic Acrisols & 4 & Slope & $<80$ & 4 \\
\hline & Xanthic Ferralsols & 3 & & $80-150$ & 3 \\
\hline & Ferralic Acrisols & 1 & & $150-200$ & 2 \\
\hline & Plinthic Acrisols and Dystric Fluvisols & 1 & & $>200$ & 1 \\
\hline \multirow[t]{3}{*}{ Soil texture } & Clay & 2 & $\mathrm{pH}$ & $4.5-5.0$ & 3 \\
\hline & Sandy loam & 1 & & & \\
\hline & Silt clay loam & 3 & & $4.0-4.5$ & 2 \\
\hline \multirow[t]{4}{*}{ Soil thickness } & $70 \mathrm{~cm}-100 \mathrm{~cm},>100 \mathrm{~cm}$ & 4 & Soil organic matter content & $>2$ & 3 \\
\hline & $50 \mathrm{~cm}-70 \mathrm{~cm}$ & 3 & & & \\
\hline & $30 \mathrm{~cm}-50 \mathrm{~cm}$ & 2 & & $<2$ & 2 \\
\hline & $<30$ & 1 & & & \\
\hline
\end{tabular}




\subsection{Suitability of land area for rubber plantation}

The physical land suitability map for rubber plantation was created based on a land unit map, scored according to the suitability level for each factor. ArcGIS 10.3 software was used to develop the map. The map displayed in Figure 3, shows that the score of land suitability fluctuate from 1.75 to 3.55 , meaning that land suitability ranges from not suitable (N) to very suitable (S1) respectively. Because of soil thickness has the highest impact on rubber plantation, land units, that have an overall land suitability score, display more than 1.75. However, the sub-score of soil thickness is 1 (not suitable), therefore, they also are rated as $\mathrm{N}$ level.

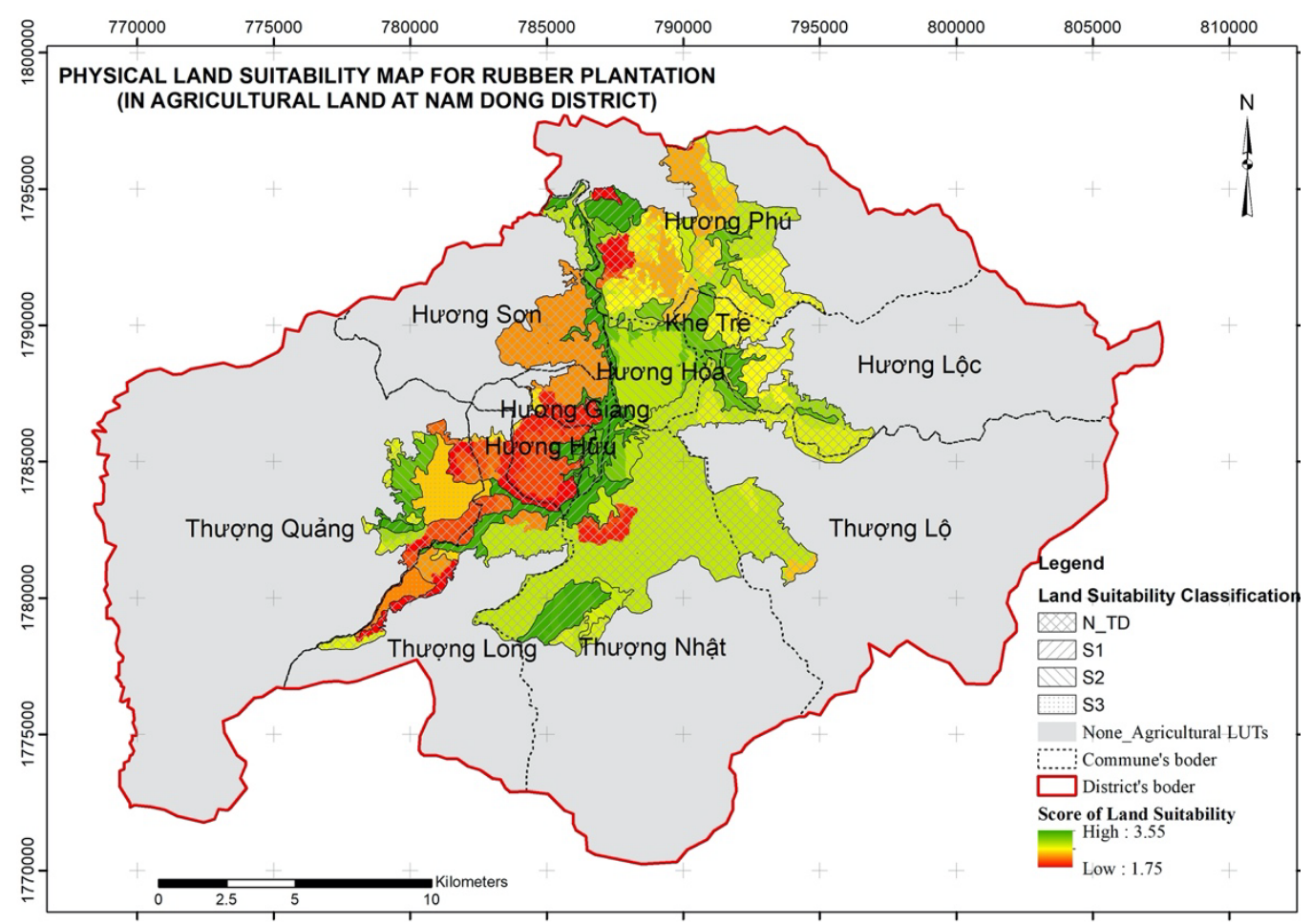

Figure 3: Physical land suitability map for rubber plantation

The agricultural land area for each suitability level is shown in Table 7. Data reveals that, in this district, the range changes among land suitability levels regarding to FAHP method.

Table 7. The area of each land suitability level by commune

\begin{tabular}{lllll}
\multirow{2}{*}{ Commune } & \multicolumn{4}{l}{ The agricultural land area (ha) } \\
\cline { 2 - 5 } & S1 & S2 & S3 & N \\
\hline Huong Giang & 183.78 & 55.89 & & 423.81 \\
Huong Huu & 98.46 & 35.91 & 659.97 \\
Huong Hoa & 44.64 & 879.12 & 233.28 \\
Huong Loc & 84.06 & 80.28 & 817.38 \\
Huong Phu & 198.18 & 457.38 & & 2613.78 \\
Huong Son & 199.62 & 3.87 & & 996.03 \\
Khe Tre town & & 194.67 & & 216.81 \\
Thuong Lo & & 103.23 & & 1118.48 \\
Thuong Long & 211.22 & 25.83 & 171.36 & 1111.32 \\
Thuong Nhat & 580.50 & 385.56 & & 2724.84 \\
Thuong Quang & 46.53 & 274.5 & 405.09 & 611.37 \\
Total & 1646.99 & 2496.24 & 576.45 & 11527.1 \\
\hline
\end{tabular}

The available area for each suitability class, identified by weight overlay, shows that a large area is currently not suitable for rubber plantation; about 11,527 ha, accounting for over $70 \%$ of the study area. The main reason for this outcome is the prevalent soil thickness in the Nam Dong district, fluctuating from 30 to $70 \mathrm{~cm}$ which could not adapt to the growth requirement of rubber tree.Because of the rubber tree has roots made up of a tap-root and creeping roots that plunge into the ground need at least $70 \mathrm{~cm}$ to ensure that the tree does not break down. The total area rating as very suitable and suitable levels for rubber plantation account for over 25\%, mainly concentrating in the communes of Huong Giang, Huong Hoa, Huong Phu, and Thuong Nhat.

Regarding this result 576.45 ha, equivalent to $3.6 \%$ of the total agricultural land area is slightly suitable for rubber tree growth. The land suitability level for rubber plantation depends on the collected data of soil characteristics and the crop requirements. Results are also based on the weight assigned to each factor used in the land evaluation procedure. Also, a limited factor method (soil thickness) was used to suitability classification. The results show that the most important factors for the growth of rubber trees were related to topology and soil physical characteristics such as slope, soil thickness, soil textures and soil type. 
These limited factors could have had an impact in the land suitability classification, either individually in groups.

For the factor related to soil chemical characteristics (soil $\mathrm{pH}$ and soil organic matter content) it could be improved in the future by technical measurements. In comparison to current land use maps of the Nam Dong district, there are some differences with our research outcomes. According our findings, some areas in the Huong Phu and the Huong Son communes are very suitable for rubber trees plantation, however, they are used for other crops.

As demonstrated by previous research, land use decisions are dependent on many factors, including natural and ecosocial issues. Nevertheless, this research focused only on natural factors, not reflecting the land use needs of local people. This indicates that a multi-disciplinary approach for land use research is needed for better results.

\section{Conclusion}

Effective tools to physical land suitability evaluation are the FAHP and GIS-based methods. Besides the FAO framework, the AHP method could approach and solve the suitability classification by the weighting of critical factors. This research found out that different criteria exert different effects and that weigh values need to be consider in land evaluation. Soil thickness has the highest impact on the rubber tree plantation suitability analysis while soil pH has the lowest. For the agricultural areas in the Nam Dong district, there were four levels of land suitability classification for rubber plantation varying from S1 to N.

Most of the area was classified as N (over 70\%). The remaining 30\% includes S1, S2 and S3 classes, accounting for 1,646.99 ha, 2,496.24 ha and 576.45 ha respectively. The agricultural areas of the Huong Phu, Huong Giang, Thuong Nhat, and Thuong Quang communes are the most suitable for rubber plantation. The land suitability scenarios presented in this research can provide a reference to make right decisions on land use planning, recommending to investment in improving soil quality and to increase the efficiency of agricultural production.

\section{Acknowledgments}

This research was funded by Hue University via grant number DHH2020-02-138.

\section{References}

[1] AbdelRahman, M. A., Natarajan, A., \& Hegde, R. (2016). Assessment of land suitability and capability by integrating remote sensing and GIS for agriculture in Chamarajanagar district, Karnataka, India. The Egyptian Journal of Remote Sensing and Space Science, 19(1), 125-141. doi: 10.1016/j.ejrs.2016.02.001.

[2] Asakereh, A., Soleymani, M., \& Sheikhdavoodi, M. J.
(2017). A GIS-based Fuzzy-AHP method for the evaluation of solar farms locations: Case study in Khuzestan province, Iran. Solar Energy, 155, 342-353. doi: 10.1016/j.solener.2017.05.075.

[3] Ayhan, M. B. (2013). A Fuzzy Ahp Approach for Supplier Selection Problem: A Case Study in A Gearmotor Company. International Journal of Managing Value and Supply Chains, 4(3), 11-23. doi:10.5121/ijmvsc.2013.4302.

[4] Debesa, G., Gebre, S. L., Melese, A., Regassa, A., Teka, S., \& Tejada Moral, M. (2020). GIS and remote sensingbased physical land suitability analysis for major cereal crops in Dabo Hana district, South-West Ethiopia. Cogent Food \& Agriculture, 6(1), 25. doi:10.1080/23311932.2020.1780100.

[5] Fahrul, A., Rahmat, S., \& Heliza, R. H. (2014). Fuzzy analytical hierarchy process for land suitability analysis compared to analytical hierarchy process. In International Conference on Science and Technology for Sustainability.

[6] FAO. (1976). A framework for land evaluation. FAO soils bulletin: Vol. 32. Rome: Food and Agriculture Organization of the United Nations.

[7] H. I. Mohammed, Z. Majid, N. B. Yusof, \& Y. B. Yamusa (2017). GIS-based and multi-criteria evaluation method for optimised landfill site selection: a review. In Global Civil Engineering Conference.

[8] Heliza, R. H., Rahmat, S., Fahrul, A., \& Tarbiyatul, M. (2014). Fuzzy analytical hierarchy process for land suitability analysis. In International Conference on Science and Technology for Sustainability.

[9] Herzberg, R., Pham, T. G., Kappas, M., Wyss, D., \& Tran, Chau Thi Minh. (2019). Multi-Criteria Decision Analysis for the Land Evaluation of Potential Agricultural Land Use Types in a Hilly Area of Central Vietnam. Land, 8(6), 90. doi:10.3390/land8060090.

[10] Nguyen H.H, Pham V.V, \& Khuong M. H. (2019). Applying AHP method and GIS to evaluate land suitability for paddy rice crop in Quang Xuong district, Thanh Hoa province. Can Tho University Journal Science, 11(3), 1-10.

[11] Nguyen, Hoang Khanh Linh, Jan, D., Nguyen, B. N., \& Tran, Thi Minh Chau. (2018). Mapping Risk of Landslide at A Luoi District, Thua Thien Hue Province, Vietnam by GIS-Based Multi-Criteria Evaluation, 15(1).

[12] Selassie, Y. G., Ayalew, G., Elias, E., \& Getahun, M. (2014). Soil Characterization and Land Suitability Evaluation to Cereal Crops in Yigossa Watershed, Northwestern Ethiopia. Journal of Agricultural Science, 6(5). doi:10.5539/JAS.V6N5P199. 